\title{
Atividade paranormal (EUA, 2009) e o agenciamento das categorias de tempo e espaço para a produção da narrativa de terror ${ }^{1}$
}

\author{
Paranormal activity (USA, 2009) and the assemblage \\ of time and space categories to produce a horror narrative
}

\author{
José Luís de Oliveira e Silva²
}

Resumo: $O$ presente texto levanta a reflexão sobre as formas como as categorias tempo e espaço, singulares para a experiência histórica dos sujeitos, são revestidas de características ameaçadoras em Atividade paranormal. Assim, a proposta é pensar como essas categorias atuam conjuntamente na narrativa para a construção do terror psicológico entre as personagens do filme e que é sentido por parte de seus espectadores.

Palavras-chave: terror, espaço, tempo.
Abstract: The present paper reflects upon how time and space categories, unique to the subjects' historical experience, are coated with menacing features in Paranormal Activity. Therefore, its proposition consists in considering how such categories act together to create, among the film's characters, a psychological horror that is also felt by its viewers.

Keywords: horror, space, time.

\section{Palavras iniciais: localizando e problematizando o objeto}

Atividade paranormal ${ }^{3}$ - roteirizado, produzido, dirigido e editado pelo até então desconhecido programador de jogos para videogames, Oren

\footnotetext{
${ }^{1} \mathrm{O}$ texto é fruto das reflexões desenvolvidas e apresentadas durante a coordenação do Simpósio Temático Histórias, narrativas visuais e produção de sentidos, realizado por ocasião do Congresso Internacional de História e Patrimônio Cultural - Teresina-PI, 2010.

${ }^{2}$ Licenciado em História pela Universidade Estadual do Piauí; Especialista e Mestre em História do Brasil pela Universidade Federal do Piauí; Doutorando em História pela Universidade Federal de Goiás. Professor do Instituto Federal de Educação, Ciência e Tecnologia do Piauí/ IFPI. Atualmente desenvolve pesquisas que envolvem História, ensino e linguagens, em especial a cinematográfica. E-mail: jlclio@yahoo.com.br

${ }^{3}$ Atividade paranormal. Direção: Oren Peli. Atores: Katie Featherston, Micah Sloat, Mark Fredrichs, Ashley Palmer, Amber Armstrong. EUA, 2009. 86 min. DVD.
} 
Peli -, já entrou para a história do cinema como uma das produções mais lucrativas de todos os tempos. Gravado em apenas uma semana, e contando com uma modesta receita de 11 mil dólares, o filme, em seu primeiro final de semana em salas de cinema dos Estados Unidos, arrecadou algo próximo a 10 milhões de dólares em bilheteria, quantia que, após uma viral divulgação através de páginas da internet, rapidamente ultrapassou a cifra dos 115 milhões de dólares em salas de todo o mundo. Oren Peli, conscientemente, se beneficia das potencialidades publicitária e comercial de novos veículos - sobretudo a internet - para alavancar o sucesso de seu filme: dá alternativas de finais, faz campanha incitando o clamor popular em prol da exibição do filme, vincula ao filme histórias inventadas como se fossem reais.

Atividade paranormal se insere no que se convencionou chamar de filmes found-footage, ou seja, produções de baixíssimo orçamento que buscam misturar técnicas de documentário, cine-jornalismo e ficção. $\mathrm{O}$ filme copia a receita de outra referência found-footage do gênero terror, $A$ bruxa de Blair (1999), no sentido de conseguir incutir entre a maior parte de seus espectadores a certeza de que a história narrada é baseada em fatos reais. Esse artifício propagandístico é fundamental para se chegar à situação de medo que o filme suscita em seus espectadores, pois a maioria irá encarálo numa perspectiva documental.

Kendall Walton, ${ }^{4}$ ao estudar as reações de temor frente a filmes de ficção, aponta para o fato de que uma pessoa só pode desenvolver a experiência de medo real frente a algo quando "acredita que ele exista, ou que, ao menos, possa existir", ou seja, toma "o filme por um documentário ao vivo, ou um telejornal". Caso contrário, segundo o próprio Walton, o espectador, no máximo, desenvolve um estado semelhante ao medo - um "quase-medo" em suas palavras. A ideia defendida pelo teórico é a de que os sentimentos variam de acordo com a possibilidade de distanciamento do espectador em relação à história que ele acompanha na tela: esse distanciamento é o que possibilita uma sensação de "terror controlado" e, consequentemente, a certeza de que, apesar dos sustos, ele está seguro na sala de cinema ou em sua casa.

Atividade paranormal é sintomático do momento em que vive a indústria cinematográfica norte-americana e pode apontar alternativas possíveis para a convivência dos grandes estúdios hollywoodianos com a

\footnotetext{
4 WALTON, Kendall. Temores fictícios. In: RAMOS, Fernão Pessoa (org). Teoria contemporânea do cinema. São Paulo: Editora SENAC São Paulo, 2005. v.2, p.105-125.
} 
crise financeira que já entra na sua terceira década, já que se baseia numa receita de baixo orçamento e alta lucratividade. Entender o sucesso e a lucratividade desse filme passa, necessariamente, por entender o fenômeno das inter-mídias que marca o cotidiano e a produção cultural contemporâneos. É importante ressaltar que intermídia é um conceito trabalhado pelo teórico norte-americano Henry Jenkins, ${ }^{5}$ e diz respeito ao aumento das possibilidades de experiências do espectador/consumidor frente ao produto cultural de seu interesse. Analisa, sobretudo, a relação construída entre mídias de linguagens diferentes: hoje muitos espectadores não se satisfazem em apenas ver um filme, eles enchem com seus comentários blogs especializados, buscam continuidades para as histórias em outros suportes (jogos eletrônicos, por exemplo), produzem escritas que comentam, completam ou estendem o sentido das histórias que acompanham etc.

Quanto ao filme, a lógica que estrutura sua narrativa é relativamente simples e não traz grandes inovações técnicas ou temáticas ao gênero terror, o que pode, de início, desqualificar uma reflexão pontual acerca das questões mais amplas que ele pode instigar. A história narrada se resume à experiência de um casal de namorados - Katie (jovem que afirma ser perseguida, desde criança, por um estranho demônio) e Mica (o namorado cético que resolve comprovar a falsidade das histórias gravando, com uma câmera caseira, as noites de sono do casal) - frente, como o título explicita, à comprovação de atividades paranormais em sua própria casa durante o correr das noites. Além desse núcleo, outras duas personagens aparecem de forma esporádica: um especialista em fenômenos paranormais e uma amiga do casal. Essas personagens, embora secundárias, são necessárias para a manutenção da trama e da tensão no filme; são elas que explicam aos protagonistas e, consequentemente, aos espectadores, que não adianta fugir do problema, pois o mesmo não está ligado à casa, mas à personagem Katie e, desse modo, justifica a permanência naquele local.

A última personagem da história é a criatura demoníaca causadora dos fenômenos. O que particularmente me interessa são os mecanismos utilizados para desencadear reações de medo no espectador, já que a presença desse demônio ficará sempre subtendida e denunciada apenas com manifestações sonoras ou relacionadas às mudanças materiais no ambiente: o demônio não se materializa em personagens de feições assustadoras como de costume em filmes de terror. Sua presença é perceptível apenas por

\footnotetext{
${ }^{5}$ JENKINS. Henry. A cultura da convergência. São Paulo: ALEPH, 2009.
} 
mudanças na casa: torneiras que aparecem abertas, lustres e portas que se movem, luzes que acendem e apagam voluntariamente, sons que parecem sair das paredes e passos pela casa. Aqui, começo a delinear minha hipótese, qual seja, que o espaço da casa, ou melhor, o seu agenciamento, embora não sendo o provocador das atividades paranormais, é a chave para a compreensão do terror que povoa o filme.

A questão que levanto é pensar o(s) porquê(s) de um filme como Atividade paranormal, sem sangue ou violência gratuita, poder suscitar uma experiência de terror em seus espectadores. Entendo, a princípio, que uma feliz e bem pensada combinação entre técnicas cinematográficas e o jogo de significados assumidos pela espacialidade e temporalidade - duas categorias-chave para a experiência histórica dos sujeitos - no filme são responsáveis pela construção da atmosfera aterrorizante que cerca o casal protagonista e que é projetada sobre o espectador. Nesse ponto, cabe levantar algumas questões que considero centrais para desenvolver minha reflexão: como as técnicas de filmagem (enquadramento, iluminação, sonorização) ajudam a chegar ao resultado esperado para uma história de terror? Como o filme trabalha com as categorias de tempo e espaço e como estas funcionam na construção de um terror psicológico para personagens e, sobretudo, espectadores? Como uma análise mais cuidadosa do filme pode contribuir para pensar aspectos do tempo presente que envolvem a sua própria produção e, sobretudo, o seu consumo?

Para jogar luz sobre essas questões adoto um caminho didático. Primeiramente farei uma reflexão acerca do terror enquanto gênero cinematográfico e, em seguida, trabalharei mais diretamente com os jogos de sentido que o filme utiliza em relação à espacialidade e à temporalidade que marcam a história narrada. Por traz de toda a discussão está a convicção da necessidade de se pensar o espaço e o tempo como categorias significadoras das experiências culturais dos indivíduos em sociedade.

\section{Terror: experiência de catarse frente ao filme Atividade paranormal}

O que poderia explicar o fato de pagarmos para sentirmos medo, termos espasmos, perder noites de sono em meio a pesadelos e, em casos mais extremos, passarmos mal por sustos causados por um filme de terror? $\mathrm{Na}$ verdade, o que pode mesmo ser considerado um filme de terror? Que situações e personagens podem ser caracterizados como comuns e essenciais ao gênero? Ao contrário do que possa parecer à primeira vista, o terror não é facilmente diagnosticável, muitas vezes ele se mistura e se 
confunde com outros gêneros cinematográficos - thriller, ficção científica, fantástico, ação. Ciente da dificuldade de precisar o que seja um exemplo de filme de terror, Luís Nogueira propõe enumerar dois aspectos que, segundo ele, são essenciais a um filme dessa natureza:

Por um lado, a centralidade narrativa e dramática da vítima, com a qual o espectador é convidado a se identificar, muitas vezes através da usurpação de seu ponto de vista. É nessas circunstâncias que o espectador partilha com a vítima seu maior medo. Por outro lado, a tendência de muitos filmes para a apresentação explícita e muitas vezes exagerada dos efeitos físicos e psíquicos dessa mesma violência sobre as vítimas. ${ }^{6}$

Outros autores vão ainda mais longe e tentam fazer uma cartografia dos tipos de mortes e criaturas que devem povoar um bom filme do gênero. Entre esses, encontramos casos pitorescos de enumeração dos tipos de morte: a morte na forma personificada e materializada (exemplo de $O$ sétimo selo - 1957); a morte representada através de um psicopata ( $O$ massacre da serra elétrica - 1974 e Jogos Mortais - 2004); a morte motivada por possessão demoníaca (O Exorcista - 1973) e - em minha opinião a mais curiosa tentativa de classificação - a morte representada por criaturas ou elementos da natureza (Os Pássaros - 1963, Tubarão - 1975 e Fim dos Tempos -2008). ${ }^{7}$ Desnecessário explicar o quanto essa tentativa de classificação se mostra arbitrária e confusa, bastando tomar como exemplo o próprio Atividade paranormal, que escapa a esses engavetamentos, uma vez que a morte se apresenta apenas como uma possibilidade, ou o equívoco de classificar filmes como $O$ sétimo selo, Tubarão e Fim dos Tempos como filmes de terror.

Independente da utilização, ou não, de convenções classificatórias, acredito que para uma reflexão acerca do gênero terror e, sobretudo, da experiência dos espectadores frente a filmes desse tipo, é válido o resgate de uma categoria conceitual aristotélica: a catarse. O conceito, em Aristóteles, embora remeta à tragédia, está ligado à ideia de purgação de medos

\footnotetext{
${ }^{6}$ NOGUEIRA, Luís. Manuais de cinema II: gêneros cinematográficos: Covilhã: Livros LabCom, 2010. p. 38.

7 SANTIAGO, Luiz. Apontamentos sobre o terror no cinema. Disponível em $<$ http://cinebuli.blogspot.com>. Último acesso: 21 ago. 2010.
} 
pessoais, ou seja, a purificação provocada por infortúnios que acometem a trajetória de vida de um indivíduo.

No filme que tomo como foco para análise nesse artigo, a catarse pode ser pensada sob duas perspectivas: 1) como elemento central para a manutenção do estado de tensão do espectador frente à história que acompanha, ou seja, há um compadecer-se com o infortúnio do namorado que, por brincadeira e descrença, resolve provocar e se envolver numa situação que o espectador já prevê que não irá acabar bem; 2) como a busca do prazer através do sofrimento, na medida em que o fascínio do especatdor provém do desconforto provocado pela história aterrorizante que ele acompanha. Em outras palavras, o espectador se vê na possibilidade de purgar os seus medos do desconhecido através da contemplação de uma obra ficcional.

Nogueira assim resume os efeitos da catarse em espectadores:

Se o filme de terror procura sempre provocar alguma espécie de efeito emocional nefasto no espectador, a tipologia desses efeitos pode ser bastante diversa: o medo, o terror, a repulsa, o choque, o horror, a abjeção. Nos seus mais característicos e mais extremos momentos, estes efeitos e estas experiências emocionais podem revelar-se quase insuportáveis e levar a diversas manifestações radicais: fugir com o olhar, sentir náuseas, gritar estridentemente, suar compulsivamente ou mesmo abandonar a sala de cinema são algumas das reações possíveis. ${ }^{8}$

Tomemos esse gancho explicativo para pensar alguns depoimentos emblemáticos de espectadores de Atividade paranormal que registraram suas experiências frente ao filme:

Nossa! Eu não dormi a noite toda com medo da guria! Vocês também ficaram imaginando onde estará ela hoje??? Creedo que medoo! E pior é que parece que o filme é o original, que são eles mesmos, e se for??? Nossa que medo! Eu amo esse tipo de filme, mas morro de medo dessas coisas, a gente que gosta disso leva tudo numa boa né?, é tudo mentira tudo bem, mas

\footnotetext{
${ }^{8}$ NOGUEIRA, Manuais de cinema II, op.cit. p. 36.
} 
quando falam que foi "baseado" em fatos reais e com uma filmagem caseira, é de apavorar mesmo!

Rapaz, muitíssimo assustador, não dormi a noite inteira com medo, muito medo, mas eu gostei, acho que é a realidade de uma pessoa, mas queria que não fosse. [grifos meus] ${ }^{9}$

Esses dois depoimentos - vários outros poderiam ter sido citados por trilharem o mesmo caminho - reforçam algumas das colocações que eu havia levantado anteriormente, senão vejamos:

1. Há, de modo geral, um poder de convencimento de que a história narrada é baseada em fatos reais. Em alguns casos, chega-se mesmo a aceitar as imagens como registros de ataques reais. Essa aceitação se deve a dois motivos: a intensa propaganda à qual já me referi e a escolha de uma técnica de filmagem (próxima do documentário amador) responsável por criar a sensação de serem imagens "caseiras";

2. Não obstante "morrerem de medo" desse tipo de filme e, consequentemente, sofrerem as consequências de assisti-los (insônia e sustos), esses espectadores não conseguem controlar sua atração pelo gênero. Aqui parece caber perfeitamente a ideia da catarse, nesse caso envolvendo o próprio espectador que faz a escolha de assistir a um determinado filme sabendo das consequências negativas que ele trará, ou seja, resumidamente, é a escolha de desafiar os seus medos través de uma obra ficcional.

\section{Os artifícios do terror: técnicas narrativas em Atividade paranormal}

Como afirmei anteriormente, Oren Peli, deliberadamente, provoca a crença de que sua produção se trata de uma adaptação crua de episódios que marcaram a vida de um casal norte-americano. Para isso, o diretor faz uma série de escolhas narrativas que são responsáveis por imprimir uma

\footnotetext{
${ }^{9}$ Os depoimentos citados nesse texto foram extraídos do site <www.filmesdecinema.com.br> (último acesso: 20 ago. 2010). Embora mantendo algumas gírias e formas de pontuação comuns a textos vinculados nesse tipo de mídia (modificá-las interferiria na captação dos sentidos e sentimentos que querem transmitir), dei-me o direito de "correção" em desvios da norma padrão.
} 
atmosfera documental e "caseira" ao filme. Começo a análise dessas escolhas narrativas pelas palavras que encerram o filme: ${ }^{10}$

O corpo de Mica foi descoberto pela polícia no dia 11 de outubro de 2006. O paradeiro de Katie permanece desconhecido.

Entendo que essa simples afirmação é central para a impressão documental do filme, pois a mesma se constrói sobre quatro pressupostos comumente vistos, pelo grande público, como fundamentais para a aceitação de uma história como sendo verídica: o conhecimento do evento (a morte de um indivíduo), das personagens envolvidas (o casal Mica e Katie), sua datação temporal (dia/mês/ano) e, é claro, a prova material de sua ocorrência (o corpo sem vida). O alcance dessas palavras finais é ampliado pela técnica de datar detalhadamente ano, dia e hora em que os eventos filmados teriam acontecido (as atividades teriam sido filmadas no decorrer de 21 noites, entre os dias 18 de setembro e 8 de outubro de 2006). Não obstante esse artifício de fechamento, o filme é todo pensado dentro de técnicas cinematográficas, sobretudo do documentário, que, juntas, são responsáveis pelo "efeito de real". Aqui, tratarei de três dessas técnicas: o ponto de vista da câmera, os jogos de luz e os efeitos sonoros.

Por ponto de vista da câmera entende-se a sua localização, o que faz gerar o ponto de observação a partir do qual a cena é olhada. Em Atividade paranormal essa câmera é colocada repetidamente sobre móveis da casa (o que, geralmente, não possibilita um bom enquadramento das personagens que, por isso, aparecem com partes de seus corpos "cortados") ou nos braços da personagem Mica (gerando uma incômoda imagem desfocada e trêmula). Essa técnica, longe de denunciar o amadorismo, desconhecimento ou precariedade dos equipamentos de gravação, tem a função de dar ao filme o aspecto de um documentário amador, feito por pessoas comuns. Outra função, sobretudo quando a câmera se acha nos braços da personagem e funciona como seus olhos (câmera subjetiva), é a de jogar o espectador no interior da narrativa do filme: se a câmera é os olhos da personagem e estes, por sua vez, são os olhos que guiam o espectador, subentende-se que a

\footnotetext{
${ }^{10}$ Em artigos de jornais e revistas consultados há uma espécie de espanto em relação ao fato do filme não apresentar os créditos finais com os nomes e funções de sua equipe produtora essa ausência é, entre a grande maioria de críticos, entendida como indício do amadorismo da produção. A meu ver, a falta dos créditos finais se configura em artifício narrativo que reforça a crença de que as imagens exibidas são uma captação de eventos reais, logo, não produzidas por uma equipe que mereça ser lembrada.
} 
exposição de Mica aos possíveis perigos provocados pelos fenômenos paranormais passa a ser, também, uma exposição de quem assiste ao filme ou, pelo menos, a sensação momentânea de que está sendo exposto ao perigo.

Outra técnica bastante utilizada em Atividade paranormal, com vista a construir o sentimento de estar vendo um filme caseiro, é o jogo de campo/contracampo através de espelhos e as falas diretas das personagens à câmera: querendo acabar com a sensação de ficcionalidade, já não há mais necessidade de omitir a presença da câmera e de microfones; ao contrário, esses são incorporados como peças-chave para a construção do efeito esperado da narrativa.
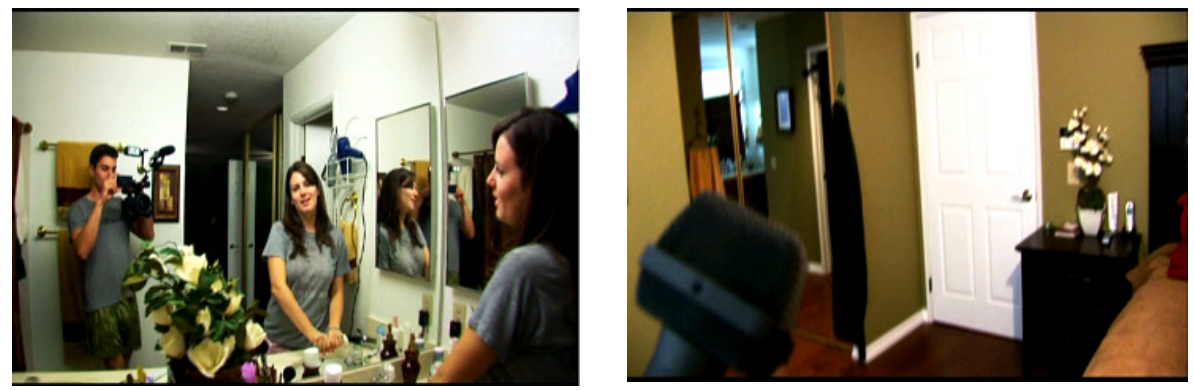

O jogo de espelhos que permite a Mica captar a imagem da namorada ao mesmo tempo em que também capta a sua própria imagem. Aliados à exposição de microfones, esses artifícios constroem a mensagem de que naquela filmagem não há truques, que as coisas acontecem e são mostradas sem maquiagem.

Talvez o mais importante, para as pretensões do filme, seja a escolha do enquadramento das imagens do quarto do casal, lugar onde os fenômenos paranormais se manifestam com mais intensidade. As imagens que captam a cama do casal estão relacionadas a uma técnica conhecida como "equilíbrio das massas": quando o objeto/sujeito está excessivamente descentralizado em relação ao quadro da imagem, o vazio de sua presença é preenchido pela incorporação de elementos que se reúnem em torno dele. A questão é que, ao contrário do que possa parecer, a centralidade, no sentido de importância assumida na narrativa, não está na cama onde o casal está deitado, mas na porta aberta que dá acesso ao corredor e à escada da casa. São o corredor e a escada, ou melhor, o que pode vir deles, que causam a tensão e a expectativa do susto, no filme. 
Isso explica o porquê da porta do quarto estar sempre aberta, mesmo o espírito não conhecendo barreiras físicas para se locomover. O detalhe que faz uma grande diferença na construção do terror psicológico do filme é que essa porta não dá acesso a lugares significados, ao contrário, dá acesso a lugares de fluxo, de passagem - o corredor e a escada - que por sua vez dão acesso a outros cômodos desconhecidos de quem vê o filme. Em outras palavras, Atividade paranormal joga com os sentidos de insegurança que o desconhecimento do espaço pode suscitar.
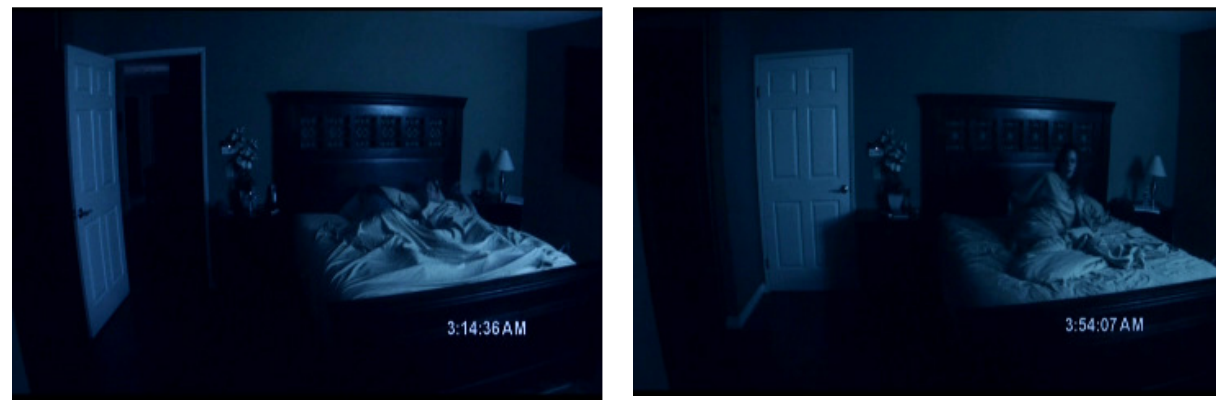

Nas imagens fica claro que a atenção é deslocada do casal que poderá sofrer algum mal para o lugar de onde esse mal deve surgir.

A luz no filme é outro componente desencadeador de tensão e medo. A câmera utilizada por Mica é uma câmera caseira com luz limitada e, por vezes, após o casal ouvir barulhos estranhos pela casa, é a única a iluminar os passos das personagens em suas andanças pelo ambiente escuro. A utilização de uma luz direta e, ao mesmo tempo, de curto alcance, reduz a profundidade de visibilidade das imagens, provocando a desconfortante sensação de que algo de terrível pode estar bem próximo, porém, fora do alcance dos olhos. Mais uma vez, o que o espectador sente não é o medo de uma criatura visível e conhecida, mas a tensão provocada pela expectativa de que esta poderá saltar das sombras a qualquer momento e gerar algo terrível na trama narrada, causando-lhe um grande susto. Outro papel do jogo de luz na construção/manutenção do terror no filme é servir como prenúncio para a chegada ou presença do demônio no ambiente da casa: mesmo nas noites mais calmas há sequências de acender e apagar de luzes no corredor e na escada.

Por último, há a função dos efeitos sonoros que povoam o filme. Atividade paranormal dispensou trilha sonora musical, os sons que 
escutamos são tão somente a fala das personagens e os ruídos pela casa. As falas são bem explícitas em relação às suas intenções; de modo geral, elas explicam a complexidade do fenômeno e relembram aos espectadores o perigo iminente ou remetem ao caráter documental do qual estou falando. São exemplos dessas falas diretas: "sair da casa não vai ajudar", "alguma coisa pode tornar esse demônio mais ativo, o que levará a se comunicar com você" (especialista em paranormalidade); "a câmera está olhando para mim" (Kate). Por outro lado, são os ruídos (batidas nas paredes, passos, gemidos e barulho de objetos se mexendo) os sons mais importantes do filme, pois remetem à fonte da qual emanam e funcionam como um sinal do ser que os provoca.

\section{A casa, o quarto, o corredor: construção do terror pelos jogos com o espaço}

Minha análise do papel do espaço na construção da sensação de medo em Atividade paranormal seguirá caminhos que durante o percurso, e ao final, devem se encontrar, pois atuam juntos e para o mesmo fim: opto por fazer uma reflexão mais ampla acerca dos sentidos que os espaços e os lugares assumem na significação da experiência cultural dos indivíduos para, posteriormente, pensar como esses significados interagem na construção da sensação de terror no filme. Como já apontei, no filme me interessa, em especial, uma reflexão mais pontual sobre a casa e três de seus locais: o quarto, o corredor e a escada.

Antes de afunilar a discussão, faz-se necessário precisar o que estou chamando de espaços e de lugares, pois, percebe-se, não estou utilizando os dois termos como sinônimos. Nesse sentido, trago como referência o pensamento de Marc Augé, ${ }^{11}$ para quem o espaço se configura numa referência plástica, mutável, abstrata e vazia de significados afetivos (ver, por exemplo, como utilizamos cotidianamente o termo espaço em referência a questões as mais díspares e escorregadias: "ciber espaço", "espaço de intimidade", "espaço aéreo"). Ao contrário de espaço, o termo lugar remete a locais revestidos pelo consumo e as experiências cotidianas dos sujeitos, estando, por isso, relacionados a uma continuidade, uma significação histórica, que marca uma posição (ver como se fala de "lugar" para marcar

\footnotetext{
11 AUGÉ, Marc. Não-lugares: introdução a uma antropologia da supermodernidade. Campinas, SP: Papirus, 1994.
} 
uma posição e lembrar uma referência: "lugar histórico", "lugar de leitura", "lugar de fala"). ${ }^{12}$

Qualquer que seja a categoria que se tome para estruturar as análises deve-se estar atento ao fato de as mesmas não remeterem apenas a uma área que pode ser medida e quantificada. Desse modo, educar nossas percepções para os sentidos provocados pela espacialidade que nos cerca, como o quer Pankow, significa uma guinada na compreensão do universo que nos rodeia; significa, também, assumir que significamos geográfica e emocionalmente, tanto quanto temporalmente, nossas experiências cotidianas. Essa educação para os sentidos dos espaços e lugares traz, também, consequências de ordem epistemológica ao ofício do historiador, ou daqueles que seguirem trajetos parecidos: a ideia é não limitar o olhar na busca da veracidade ou da realidade factual dos espaços/lugares, das tramas ou das personagens envolvidas; ao contrário, a proposta é se apropriar dessas personagens e histórias e "abri-las para a sua verdade existencial e simbolizante". ${ }^{13}$

Nesse sentido, Bachelard chama a atenção para o entrelaçamento da positividade material e da imaginação que envolve a atribuição de valores sobre os ambientes que nos cercam:

Ao seu valor de proteção, que pode ser positivo, ligamse também valores imaginados, e que logo se tornam dominantes. $\mathrm{O}$ espaço percebido pela imaginação não pode ser o espaço indiferente entregue à mensuração e à reflexão do geômetra. É um espaço vivido. E vivido não em sua positividade, mas com todas as parcialidades da imaginação. ${ }^{14}$

Quais são, então, os sentidos construídos pela espacialidade em Atividade paranormal? Começo pelo local onde a história se passa: a casa. A casa é provavelmente o local mais significado por afetos da experiência

\footnotetext{
${ }^{12}$ Interessante ver como Augé dialoga com Certeau em relação às mesmas questões, o que não inviabiliza um posicionamento divergente ao final. Resumidamente, é como se os dois teóricos trocassem os sentidos que os mesmo atribuem às categorias de espaço e lugar: para Certeau (CERTEAU, Michel de. A invenção do cotidiano: artes do fazer. Petrópolis, RJ: Vozes, 1994, p. 221-222) o espaço tem a ver com o "lugar praticado" enquanto que o lugar está ligado à disposição física dos elementos que o compõem. Essa "troca" de sentidos tem a ver com a matriz antropológica (a ideia de um "lugar antropológico") que atravessa toda a discussão em Marc Augé.

13 PANKOW, Gisela. O homem e seu espaço vivido: análises literárias. Campinas, SP: Papirus, 1988. p. 9.

${ }^{14}$ BACHELARD, Gaston. A poética do espaço. São Paulo: Martins Fontes, 2008. p. 19.
} 
humana e que, geralmente, remete a uma sensação de segurança física e/ou psíquica. Para Bachelard, dentro de uma "imaginação criadora",

[...] a casa afasta contingências, multiplica seus conselhos de continuidade. Sem ela, o homem seria um ser disperso. Ela mantém o homem através das tempestades do céu e das tempestades da vida. ${ }^{15}$

Por isso é emblemático que na literatura, ou mesmo no cinema, a busca de uma personagem por suas origens esteja, quase sempre, relacionada à volta à sua antiga morada, à casa que abrigara a sua infância e que parece proteger suas memórias. O reencontrar com um lugar, nesse caso, se confunde com o reencontro com um tempo que parecia perdido:

Voltar atrás! Reencontrar lugares que foram deixados! Para o homem são, o espaço reencontrado é também a história reencontrada. As paredes que abrigaram nossa infância, por exemplo, nos reconduzem facilmente para ela, e lembranças precisas e preciosas emergem sem dificuldade. Assim, o espaço proporciona segurança e "envolve" a história de vida.

Em Atividade paranormal temos o inverso dessa relação: a casa mesmo não sendo a responsável pelos acontecimentos, pois ela não é "malassombrada" -, ao perder as referências de segurança que estruturam suas significações mais comuns, lança sobre os espectadores a sensação de insegurança e desconforto em relação ao que se esconde no interior daquela morada. São os espaços obscuros da casa que servem de "esconderijo" para o demônio que atormenta a vida do casal e que fazem com que o espectador se mantenha tenso quanto aos sustos que estão por vir. São sintomáticos, nesse sentido, os depoimentos de alguns espectadores do filme:

Não é um filme de terror imediato! O verdadeiro terror vem depois que você volta para casa deita na cama e tenta dormir...

Eu não recomendo esse filme maligno para ninguém, pois causa um efeito ruim nas pessoas, as deixa perturbadas com insônia, enfim, não é bom, eu assisti e

\footnotetext{
${ }^{15}$ BACHELARD, A poética do espaço, op.cit., p. 26.

${ }^{16}$ PANKOW, O homem e seu espaço vivido, op. cit. p. 85.
} 
não gostei pelo efeito negativo que ele proporciona nas pessoas e na sua própria casa.

Acho que o que mais faz dar medo é o fato de ser algo que não podemos ver, não é como um terror sanguinário, que o assassino sai matando. Mas com certeza o medo não está lá na hora no cine e sim depois, quando vamos para casa e ficamos sozinhos... ${ }^{17}$

Quais são as questões sintomáticas que aparecem nesses comentários aos quais estou a me referir? Percebe-se - além de toda a atmosfera de realidade que envolve o filme e à qual já fiz menção anteriormente - que o verdadeiro medo que o filme instiga entre seus espectadores é o temor das forças que podem se esconder nos espaços mais íntimos. É temor que surge quando o espectador volta para casa e tem que ficar sozinho com seus pensamentos, relembrando que aqueles fatos macabros foram "reais". Entendo que esse temor tem uma relação direta com os jogos de significados dos espaços e dos lugares com os quais o filme trabalha.

Essa percepção da espacialidade como uma chave de leitura para o filme me leva a uma atenção especial a dois ambientes e aos seus significados possíveis: o corredor e escada. Se a casa e o quarto do casal ganham status de lugares significados, o corredor e a escada, por serem lugares de fluxo, de passagem, fogem a essa significação. A questão é pensar como a falta de significados para esses espaços de fluxo ajuda a construir o clima de terror no filme. Aqui entendo ser interessante, nesse sentido, desenvolver a reflexão tendo como referência uma nova categoria: a de "não lugares". Augé ${ }^{18}$ opõe a compreensão dos não lugares à de lugares antropológicos, ou seja, daqueles em que há o entrelaçamento da espacialidade (sua dimensão física) com significados sociais (afetos e significados historicamente construídos). Segundo o teórico, os lugares antropológicos têm pelo menos três características comuns: eles se pretendem (ou pretendemo-los) identitários, relacionais e históricos. Os não lugares, em contrapartida, são lugares pensados com vista ao trânsito, para servirem de passagem, logo, não são plenamente significados por aqueles que os utilizam já que utilizá-los significa tê-los sempre em fluxo e, assim, são a antítese dos lugares antropológicos.

\footnotetext{
17 Os depoimentos citados nesse texto foram extraídos do site <www.filmesdecinema.com.br>. Último acesso: 20 ago. 2010.

${ }^{18}$ AUGÉ, Não-lugares, op.cit.
} 

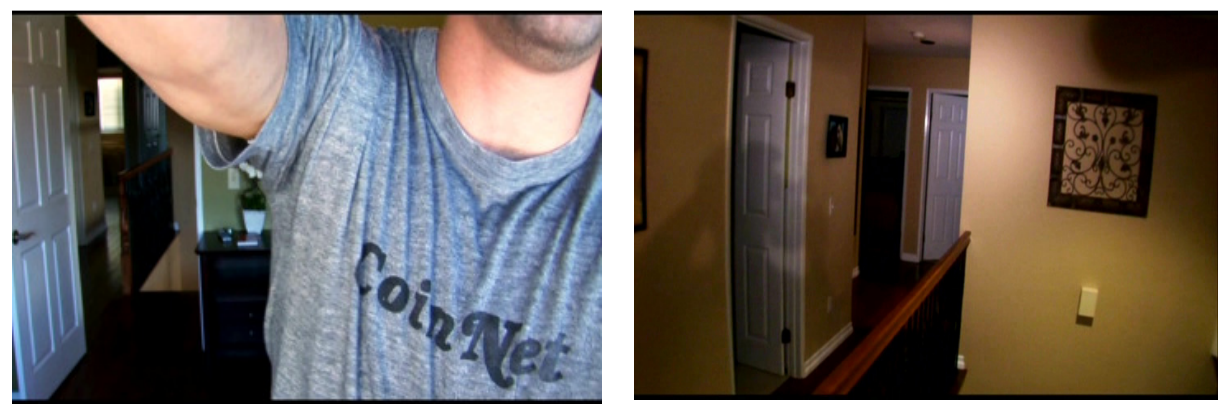

Os enquadramentos da câmera caminham no sentido de "abrir" o quarto a espaços indefinidos da casa. Vê-se nessas imagens que há uma grande quantidade de outros cômodos e que estes estão "ligados" ao quarto pelo corredor e a escada
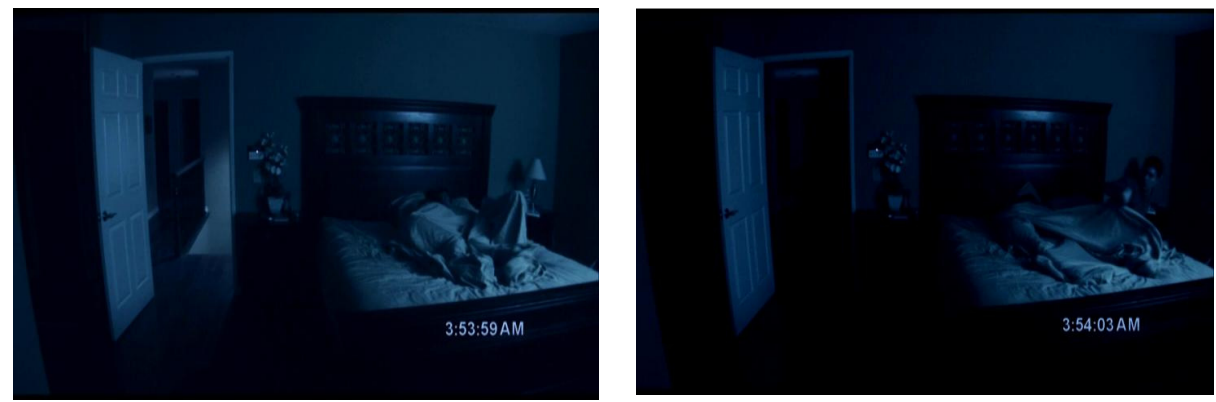

Na sequência, observa-se como o jogo de acender e apagar de luzes no corredor e na escada dá "profundidade" à dimensão desses espaços e remete à sensação de abertura e exposição do quarto à contingência de perigos imensuráveis.

Embora Augé pense em questões mais amplas quando estrutura seu raciocínio sobre os não lugares (sistemas de transporte, locais de circulação de mercadorias e pessoas, aeroportos, estações, supermercados), acredito que esses "não lugares" podem ser detectados até mesmo nos espaços mais íntimos, como os de um lar. Aqui, faço um desdobramento da minha hipótese inicial: por serem espaços de fluxo e não plenamente significados, o corredor e a escada - que se abrem e dão acesso a lugares que o espectador desconhece - são centrais para a sensação de insegurança instigada pelo filme. $\mathrm{O}$ jogo de tensão possibilitado pela imagem do quarto do casal aberto ao corredor e à escada (a porta do quarto não se abre a um outro cômodo, mas a espaços cujo itinerário pode levar a uma multiplicidade de lugares) é precisamente um dos dispositivos que sustentam a sensação de insegurança que atravessa o relato dos espectadores 
do filme, quando das suas experiências de voltarem para suas casas e se verem na necessidade de interagir com a espacialidade de seu lar.

Ao final dessa breve reflexão dos porquês de Atividade paranormal, (filme que dispensou os artifícios do sangue e violência gratuitos) suscitar uma experiência de terror em seus espectadores, chego à conclusão que minha hipótese preliminar se confirmou: os resultados e o convencimento do filme se devem, principalmente, à combinação de técnicas cinematográficas e ao jogo de significados que a produção imprime à categorias de tempo e espaço. Desse modo, cabe uma brevíssima retrospectiva de minhas conclusões.

As técnicas de filmagem - a posição de câmera (o efeito "amador"), os jogos de iluminação (a "brincadeira" de mostrar/esconder, iluminar/escurecer) e a sonorização (atento para o fato de boa parte da percepção do espectador em relação ao filme se dar no nível sonoro) ajudam a chegar à sensação de terror esperada para uma história do gênero. Por outro lado, essa sensação aterrorizante não seria alcançada sem as sutis relações que o filme estabelece com os espaços e lugares que utiliza: é sutil e fundamental a utilização do quarto, do corredor e da escada. Do mesmo modo, o trabalho de marcação temporal fecha o aspecto documental do filme e completa a possibilidade de entendê-lo como "baseado" em fatos reais. 